Journal of Maternal and Child Health (2018), 3(1): 68-80

https://doi.org/10.26911/thejmch.2018.03.01.07

\title{
Determinants of Stunting and Child Development in Jombang District
}

\author{
Vivin Eka Rahmawati'), Eti Poncorini Pamungkasari²), Bhisma Murti' ${ }^{1)}$ \\ ${ }^{1)}$ Masters Program in Public Health, Universitas Sebelas Maret \\ 2)Faculty of Medicine, Universitas Sebelas Maret
}

\begin{abstract}
Background: Stunting is a very short body state in children that goes beyond the 2 SD deficit below the child population height. Worldwide stunting affects about 162 million children under five. Indonesia is included in 17 countries that have three nutritional problems in children under five: stunting, wasting, and overweight. This study aimed to investigate the determinants of stunting and child development in children under five.

Subjects and Method: This was a retrospective cohort study conducted at Mayangan and Jarak Kulon Community Health Centers, Jombang, East Java, in Januari 2018. A total sample of 58 children were selected for this study by fixed exposure sampling. The dependent variables were stunting and child development. The independent variables were birth-length, maternal age, maternal height, maternal education, and family income. The data were collected by questionnaire. Data on birth length was taken from maternal and child record at community health center. The data were analyzed by path analysis model.

Results: The likelihood of good child development increased with maternal education $(b=1.08$; $95 \% \mathrm{CI}=0.41$ to $1.75 ; \mathrm{p}=0.001)$ and decreased with stunting $(\mathrm{b}=-0.78 ; 95 \% \mathrm{CI}=-1.46$ to -0.10 ; $\mathrm{p}=0.025)$. The risk of stunting decreased with birth-length $(\mathrm{b}=-0.90 ; 95 \% \mathrm{CI}=-1.60$ to -0.21 ; $\mathrm{p}=0.011)$ and maternal height $(\mathrm{b}=-0.92 ; 95 \% \mathrm{CI}=-1.69$ to $-0.16 ; \mathrm{p}=0.018)$. The risk of stunting increased with maternal age $<20$ y.o. or $\geq 35$ y.o. at pregnancy $(b=0.73 ; 95 \% \mathrm{CI}=-0.03$ to 1.46 ; $\mathrm{p}=0.051)$. The likelihood of maternal age $<20$ y.o. or $\geq 35$ y.o. at pregnancy decreased with higher education $(\mathrm{b}=-0.75 ; 95 \% \mathrm{CI}=-1.44$ to $-0.06 ; \mathrm{p}=0.033)$. Birth-length increased with maternal height $(b=1.07 ; 95 \% C I=0.28$ to $1.86 ; p=0.008)$ and higher family income $(b=0.93 ; 95 \% C I=$ 0.29 to $1.57 ; \mathrm{p}=0.004)$. Birth-length decreased with maternal age $<20$ y.o. or $\geq 35$ y.o. at pregnancy ( $\mathrm{b}=-0.74 ; 95 \% \mathrm{CI}=-1.48$ to $-0.01 ; \mathrm{p}=0.047$ ).

Conclusion: The likelihood of good child development increases with maternal education and decreases with stunting. The risk of stunting decreases with birth-length and maternal height, and increases with maternal age $<20$ y.o. or $\geq 35$ y.o. at pregnancy.
\end{abstract}

Keywords: child development, stunting, birth-length, maternal age at pregnancy, maternal education, and family income

Correspondence:

Vivin Eka Rahmawati. Masters Program in Public Health, Univesitas Sebelas Maret, Jl. Ir. Sutami 36 A, Surakarta 57126, Central Java. Email: vivineka74@gmail.com.

\section{BACKGROUND}

Children growth is one of the indicators of public health in monitoring the nutritional and health status of a population (Atsu, et al, 2017). In Sustainable Development Goals (SDGs), one of the goals in the health sector is the nutritional target of the community by 2030, to end all forms of malnutrition, including achieving the international target of 2025 for stunting and wasting on children and overcoming the nutritional needs of girls, pregnant and lactating women, and the elderly. Therefore, until now, stunting has become a problem in the world, especially in Indonesia which is proven by the fact that 
many Indonesian teenagers are still under the WHO standard (Ministry of Health, 2015).

Stunting is a state indicated by a very short body that goes beyond the 2 SD deficit below the median length or height of the population according to the Word Health Organization (WHO). Stunting is closely related to the toddler's nutritional status indicator based on the height / age index, so it provides an indication of chronic nutritional problems as a result of a long condition. Socio-economic factors are the factors that indirectly and fundamentally influence the occurrence of stunting (Armstrong et al., 2011) such as maternal education, maternal height, income-related poverty (Bove et al., 2012). The study conducted by (Addo et al., 2013) connects the height of the mother with the development of children. Mothers with a height $<150 \mathrm{~cm}$ are more likely to have a short child at the age of 2 years.

Not only the height of the mother, (Win et al., 2013) mentions that pregnancy in adolescents have a higher risk of malnutrition than healthy adult women. Women $<20$ years of age tend to give birth prematurely and it will affect the height of the baby. Another contributing factor is the length of the birth body (Aryastami et al., 2017). Basic Health Research of 2013 results show that $20.2 \%$ of newborns have a body length of $<48 \mathrm{~cm}$ and $3.3 \%$ of babies have a length of $\geq 52 \mathrm{~cm}$. Fikadu et al., (2014) mentions that stunting is associated with a lack of attention, memory retardation, learning disabilities and decreased cognitive function and impaired fine motor development (Nurbaeti, 2016). The low level of maternal education indirectly affects the development of the language of the child. Parents with less education tend to have a more limited vocabulary so the child may receive limited stimulation (Schady, 2011).

How big the problem is and the determinants of stunting starting from pregnancy, toddlers, school age, working age to the elderly become global concerns for the future generations (TNP2K, 2017). The period which have been gone through is essentially in accordance with the epidemiological framework along the life cycle that has been proposed by David Barker. Approach to the lifelong epidemiology model is used to analyze human life in which it describes the trigger factors of various chronic diseases caused by bad genes and unhealthy lifestyles (Barker et al., 2013). Several lifelong epidemiological studies have shown that health status in adulthood is determined since the early life, before and after birth (Murti, 2007).

All over the world, stunting affects about 162 million children under five. Global Nutrition Report 2014 shows that Indonesia is included in 17 countries that have three nutritional problems namely stunting, wasting and overweight in children under five (Ministry of Health, 2016). Short problem in toddlers reached 23.8 million in 2013. There were 4.8 million short births, and 8.9 million shortterm toddlers, and continued in schoolaged children (5-18 years) up to 20.8 million. In East Java province, the short and very short toddlers aged 0-59 months are about 26.1\% in 2016 (Ministry of Health, 2016).

An area is said to have acute nutrition if the prevalence of short toddlers in an area is less than $20 \%$ and the prevalence of underweight children is $5 \%$ or more (Ministry of Health, 2017). The preliminary study that has been done in Jombang District Health Office showed that there was 29.16\% short toddlers and very short based on the indicator of TB / U in 2016. 
That condition is a problem that cannot be solved with a simple manner and seen from one causal factor only.

Because of the high number of children with stunting, the researchers is interested in conducting a study related to stunting and stunting effects on the development of children under five with the limits of variables to be studied including the body length when born, height of mother, maternal age during pregnancy, family income during pregnancy, current educational background of the mother, and stunting and child development.

\section{SUBJECTS AND METHOD}

\section{Study Design}

This was a retrospective cohort study. The target population is all children under five. The study was conducted in Mayangan and Jarak Kulon community health centers, Jombang, East Java, in January 2018.

\section{Population and samples}

The case population was children under five with stunting, while the control population is children who are not stunting. A sample size of 174 study subjects was selected for this study by fixed exposure sampling using a ratio of $1: 2$. The number of case samples was 58 children with stunting and the control samples were 116 children who were not stunting.

\section{Study Variables}

The independent variables were maternal height, maternal age during pregnancy, current maternal education, length of childbirth, stunting and family income during pregnancy and the dependent variable was the child development.

\section{Operational Definition}

Body length at birth was defined as the length of the infant body at birth which was measured by supine. The data were taken from maternal and child monitoring book. The measurement scale was continuous, but for the purpose of data analysis, it was transformed into dichotomous, coded o for $<50 \mathrm{~cm}$ and 1 for $\geq 50 \mathrm{~cm}$.

Maternal age during pregnancy was defined as the length of time the study subject life from birth to their current pregnancy. The data were taken from maternal and child monitoring book. The measurement scale was continuous, but for the purpose of data analysis, it was transformed into dichotomous, coded o for $<20$ or $\geq 35$ years old and 1 for $20-35$ years old.

Stunting was defined as the nutritional state of children aged 0-59 months as measured by anthropometry based on body weight for age. The measurement scale was continuous, but for the purpose of data analysis, it was transformed into dichotomous, coded o for $\geq-2$ SD and 1 for $<-2$ SD.

Maternal body height was defined as a measurement index which was measured by standing using anthropometry. The measurement scale was continuous, but for the purpose of data analysis, it was transformed into dichotomous, coded $\mathrm{o}$ for $<150$ $\mathrm{cm}$ and 1 for $\geq 150 \mathrm{~cm}$.

Maternal education was defined as the last formal education level attended by the mother. The measurement scale was categorical, coded o for $<$ Senior high school and 1 for $\geq$ Senior high school.

Family income during pregnancy was defined as the average monthly income to support all family members per person per month for each individual during pregnancy. It was calculated by the average income of the last 6 months. The measurement scale was categorical, coded o for $<$ Senior high school and 1 for $\geq$ Senior high school.

Children's development was defined as the basic ability of children aged o- 6 years as the increase of the structure and function of the body in fine and gross motor 
skills, language / verbal, and socialization. The measurement scale was continuous, but for the purpose of data analysis, it was transformed into dichotomous, coded o for poor development and 1 for good development.

\section{Data Analysis}

The data analysis of the results used path analysis to determine the magnitude of the influence of variables, either the direct or indirect influences. The magnitude of the influence of independent variables (exogenous) on the dependent variable (endogen) can be seen from the coefficient of the path, the greater the coefficient of the path is, the greater the influence given from that variable is. The pathway analysis steps

Table 1. Characteristics of study subjects by gender, age of child, body length at birth, maternal height, maternal age at pregnancy, maternal education, and family income

\begin{tabular}{|c|c|c|c|}
\hline No. & Characteristics & $\mathbf{n}$ & $\%$ \\
\hline \multirow[t]{3}{*}{1.} & Children gender & & \\
\hline & Male & 97 & $55 \cdot 7$ \\
\hline & Female & 77 & $44 \cdot 3$ \\
\hline \multirow[t]{3}{*}{2.} & Children's age & & \\
\hline & $<24$ months & 143 & 82.2 \\
\hline & $\geq 24-59$ months & 31 & 17.8 \\
\hline \multirow[t]{3}{*}{3.} & Body length at birth & & \\
\hline & $<50 \mathrm{~cm}$ & 84 & 48.3 \\
\hline & $\geq 50 \mathrm{~cm}$ & 90 & 51.7 \\
\hline \multirow[t]{3}{*}{4.} & Maternal body height & & \\
\hline & $<150 \mathrm{~cm}$ & 40 & 23 \\
\hline & $\begin{array}{l}\geq 150 \mathrm{~cm} \\
\text { Maternal age at pregnancy }\end{array}$ & 134 & 77 \\
\hline 5 . & $\begin{array}{l}20-35 \text { years } \\
<20 \text { or } \geq 35 \text { years }\end{array}$ & $\begin{array}{l}128 \\
46\end{array}$ & $\begin{array}{l}73.6 \\
26.4\end{array}$ \\
\hline \multirow[t]{3}{*}{6.} & Maternal education & & \\
\hline & Low (< Senior high school) & 86 & 49.4 \\
\hline & High ( $\geq$ Senior high school) & 88 & 50.6 \\
\hline \multirow[t]{3}{*}{7 . } & Family Income & & \\
\hline & Low & 81 & 46.6 \\
\hline & High & 93 & 53.4 \\
\hline
\end{tabular}

Related to the characteristics of the age, there were 143 subjects or $82.2 \%$ children with age <24 months, while in children aged $\geq 24-59$ months, there were 31 subjects or $17.8 \%$. Almost all subjects had the characteristics of the birth length included model specification, model identification, model fit, parameter estimation, and model re-specification.

\section{Research Ethics}

The research ethics included research approval, anonymity, confidentiality and ethical approval. Ethical clearance in this study was conducted Dr. Moewardi hospital, Surakarta, Central Java.

\section{RESULTS}

\section{Sample Characteristics}

Table 1 shows that most of the research subjects were male which were 97 samples (55.7\%), and the female ones were $44.3 \%$.
$<50 \mathrm{~cm}$ for about 84 subjects or $48.3 \%$, while the length of the birth body which were $\geq 50 \mathrm{~cm}$ were 90 subjects or $51.7 \%$.

Characteristics of mother height which were $<150 \mathrm{~cm}$ were 40 subjects or by $23 \%$. Characteristics of maternal age during 
pregnancy are mostly aged 20-35 years for about 128 subjects or $73.6 \%$.

The characteristics of maternal education, currently almost all of them have a high education ( $\geq$ SMA) of 93 subjects or $50.6 \%$. It is in line with the characteristics of income families who mostly have high income for about 93 subjects or equal to 53.4 .

\section{The result of path analysis}

The data processing used Stata 13 program. Based on path analysis on the research results, the following results were obtained.

\section{a. Model Specification}

The model specification illustrates the relationship between the variables in detail. In this study, there were eight measurable variables: maternal height, maternal age during pregnancy, family income, length of birth, current mother's education, stunting, and child development.

There was a positive and direct effect between stunting and children development. The stunting child decreases the child development logit score by 0.78 (b = $0.78 ; 95 \% \mathrm{CI}=-1.46$ to $-0.10 ; \mathrm{p}=0.025$ ).

There was a direct effect between current maternal education and child development which was statistically significant. Mothers with high education increased their child development logit score by 1.08 (b = 1.08; 95\% CI $=0.41$ to $1.75 ; \mathrm{p}=0.001$ ).

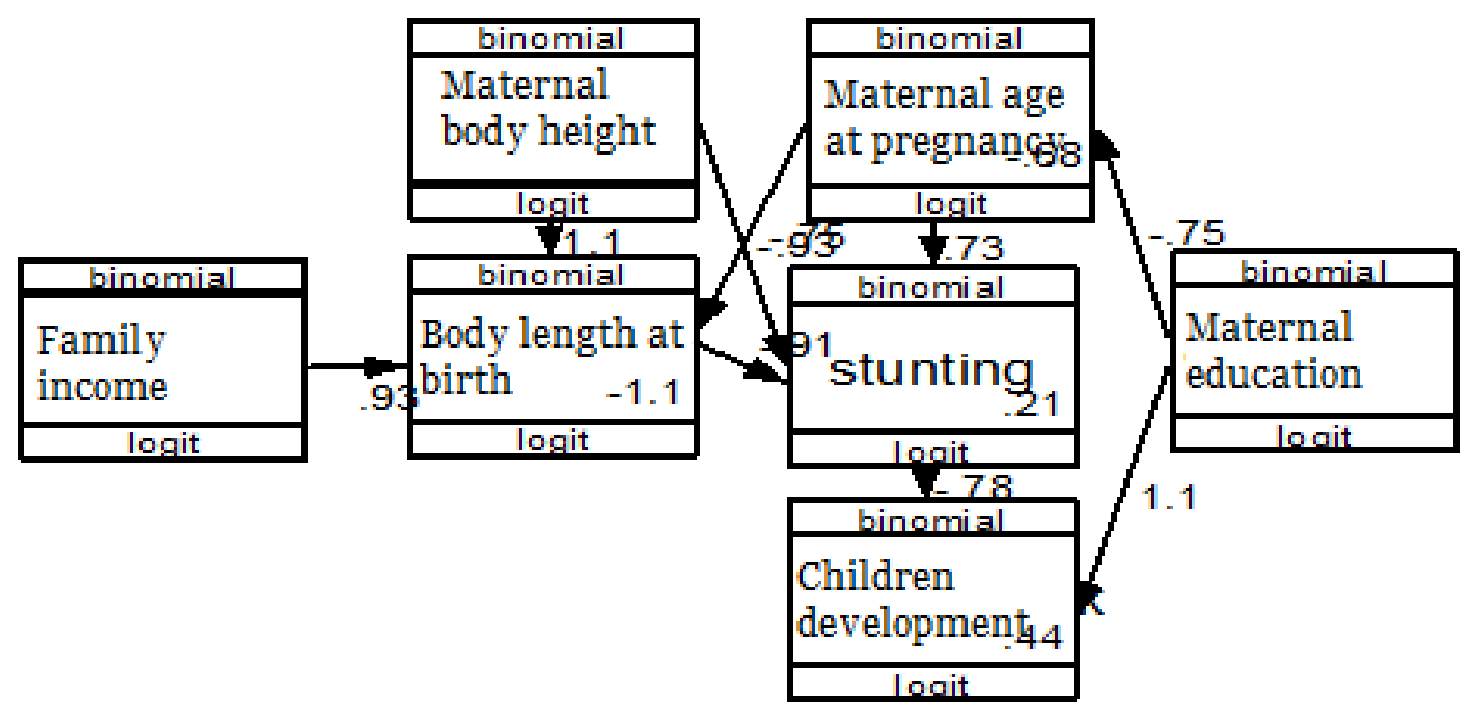

Figure 1. The Structural Model with estimate

There was a significant effect between child body weight at birth and stunting. Children born with $\geq 50 \mathrm{~cm}$ body length decreased the logit score by 0.90 units $(\mathrm{b}=$ $-0.90 ; 95 \% \mathrm{CI}=-1.60$ to $-0.21 ; \mathrm{p}=0.011)$.

There was a significant effect between maternal body height and stunting. Mother with body height $\geq 150 \mathrm{~cm}$ decreased logit score by $0.92(b=-0.92 ; 95 \% \mathrm{CI}=-1.69$ to $0.16 ; p=0.018)$.
There was an effect of maternal age at pregnancy and stunting which was statistically significant. Maternal mothers aged $<20$ or $\geq 35$ years increased their stunting logit score by 0.73 ( $b=0.73 ; 95 \%$ $\mathrm{CI}=-0.03$ to $1.46 ; \mathrm{p}=0.051)$.

There was a relationship between current maternal education and maternal age at the time of pregnancy which was statistically significant. Mothers with 
higher education ( $\geq$ SMA) had maternal age logit scores during pregnancy of $0.75(\mathrm{~b}=-$ $0.75 ; 95 \% \mathrm{CI}=-1.44$ to $-0.06 ; \mathrm{p}=0.033)$.

There was a relationship between maternal height and birth length that was statistically significant. Mothers with height of $\geq 150 \mathrm{~cm}$ increased the logit score of birth weight by $1.07(b=1.07 ; 95 \% \mathrm{CI}=0.28$ to 1.86; $\mathrm{p}=0.008)$.

There was a significant relationship between maternal age during pregnancy and children body weight at birth. Mother with $<20$ or $>35$ years of age decreased the logit score of the children body birth weight by $0.74(b=-0.74 ; 95 \% \mathrm{CI}=-1.48$ to -0.01 ; $\mathrm{p}=0.047)$.

There was a significant relationship between the family income during pregnancy and the birth weight of children. Families with high income during pregnancy increased the logit score of the children body weight at birth by $0.93(\mathrm{~b}=$ $0.93 ; 95 \% \mathrm{CI}=0.29$ to $1.57 ; \mathrm{p}=0.004$ ).

Table 2. Path analysis results of stunting determinant and children development

\begin{tabular}{|c|c|c|c|c|c|c|}
\hline \multirow[b]{2}{*}{ Dependent Variable } & \multirow{2}{*}{\multicolumn{2}{|c|}{$\begin{array}{l}\text { Independent } \\
\text { Variable }\end{array}$}} & \multirow[b]{2}{*}{$\begin{array}{c}\text { Path } \\
\text { Coefficient }\end{array}$} & \multicolumn{2}{|c|}{$95 \% \mathrm{CI}$} & \multirow[b]{2}{*}{$\mathbf{p}$} \\
\hline & & & & $\begin{array}{l}\text { Lower } \\
\text { Limit }\end{array}$ & $\begin{array}{c}\text { Upper } \\
\text { Limit }\end{array}$ & \\
\hline \multicolumn{7}{|l|}{ Direct Effect } \\
\hline Child Development & $\leftarrow$ & Stunting & -0.78 & -1.46 & -0.10 & 0.025 \\
\hline Child Development & $\leftarrow$ & Maternal Education & 1.08 & 0.41 & 1.75 & 0.001 \\
\hline Indirect Effect & & & & & & \\
\hline Stunting & $\leftarrow$ & Body length at birth & -0.90 & -1.60 & -0.21 & 0.011 \\
\hline Stunting & & $\begin{array}{l}\text { Maternal body } \\
\text { height }\end{array}$ & -0.92 & -1.69 & -0.16 & 0.018 \\
\hline Stunting & & $\begin{array}{l}\text { Maternal Age at } \\
\text { Pregnancy }\end{array}$ & 0.73 & -0.00 & 1.46 & 0.051 \\
\hline Maternal Age & $\leftarrow$ & Maternal education & -0.75 & -1.44 & -0.06 & 0.033 \\
\hline Body length at birth & $\leftarrow$ & $\begin{array}{l}\text { Maternal body } \\
\text { height }\end{array}$ & 1.07 & 0.28 & 1.86 & 0.008 \\
\hline Body length at birth & $\leftarrow$ & $\begin{array}{l}\text { Maternal age at } \\
\text { pregnancy }\end{array}$ & -0.74 & -1.48 & -0.00 & 0.047 \\
\hline $\begin{array}{l}\text { Body length at birth } \\
\text { N Observation }=174 \\
\text { Log Likelihood }=-409.93\end{array}$ & $\leftarrow$ & Family income & 0.93 & 0.29 & & 0.004 \\
\hline
\end{tabular}

\section{DISCUSSIONS}

\section{The relationship between stunting and child development}

Nutritional status in children under five years old was very influential on the process of growth. The process of growth and development of each child was differrent. Stunting children experienced growth faltering that begin in the womb up to two years old. This problem was occurred due to the lack of protein energy (LPE) as one of the main nutritional problems that occur in toddlers and was very influential in the process of child development (UNICEF, 2012).

The first two years after birth was a critical period of children's brain development. In that stage, the non-fulfillment of nutrition in children may lead to shortening apical dendrites in the brain that caused the decreased in brain function and affected the skills of motion, attention, memory, and cognitive ability (Onis et al, 2016). Therefore, the problem of malnutrition was closely related to decreased intelligence of children, and it lead to low cognitive 
development of children. It would be too late to repair the damage in the early years after the children passed the age of 2 (Hizni, et al., 2017).

Stunting was often associated with the child's survival and development. Stunting that occur at an early age would lead to a decrease in physical quality such as short body, inhibit learning achievement, low productivity of work, and increase the risk of chronic diseases in adulthood in the future (Aguayo et al., 2015).

The result of this study showed that there was a relationship between stunting and child development. This study was supported by a study done by Casale et al. (2014) which described strong and meaningful relationship between stunting and children's gross motoric and fine motoric skills.

This study is consistent with a study by Hizni et al. (2017), which stated that stunting increased the risk of delay in children's motoric development by 4 times. Developmental disorders were indicated by the slow maturation of nerve cells, motoric movement, response to the surrounding environment, and lack of intelligence of children.

\section{The relationship between current maternal education and child development}

The result of this study showed that there was a significant relationship between current maternal education and child development. This study was in line with a study by Fernald et al., (2012) which stated that family with high income and high maternal education would support good children development through provision of developmental stimulation tools such as toys, books for children, and activities that support the development of children.

Based on the description above, it can be concluded that family was the first place for children to fulfill their needs. In the family, there are parents who become teachers, role models, and mentors in every lesson for children in their daily life. But over the times, families were changing, for example, the family structure with single parents, stepfamilies, and heterosexual couples who live together in the family. If the family structure changed, the role in the family also changed. In addition, there were many parents with multiple roles as parents and employees, therefore, the time for families was reduced. Parents would have difficulty in controlling the children's behavior (Morrison et al., 2012).

Families who have high income and high education would give positive activities to their children, for example by involving their children in play groups or pre-school groups and others. In contrast, low income and low-educated families tend to watch TV than involving their children in tutoring (Decker et al., 2012).

\section{The relationship between birth- length and child development through stunting}

The result of this study showed that there was a significant relationship between birth-length and child development through stunting. This study was supported by Islam et al., (2018), who stated that a child with short birth-length has greater risk to the occurence of stunting at 12-24 months old.

The child's birth-length was determined in early pregnancy. During pregnancy, it was affected by the maternal conditions. Mothers with bad conditions such as malnutrition, stress, and have comorbidities can interfere the fetal growth. These constraints affected the development of infants with short birth-length, and would further impact on the height of the child at an early and adult age (Dorelien, 2016). 
The retardation of linear development caused by malnutrition or stunting was not only affected by the lack of nutritional intake. Other factors including infectious diseases such as diarrhea, environmental sanitation, low family income resulting in inadequate access to adequate health services, and low parental education. These factors increase the likelihood of stunting risk and delayed child development (Fernald et al., 2012).

\section{The relationship between maternal height and child development through stunting}

The result of this study showed that there was a significant relationship between maternal height and child development through stunting. The result of this study was supported by a study done by Kim et al., (2017) which stated that mothers with short height were three times more likely to have stunting in children than taller mothers. This study was in line with a study by Rahman, et al. (2016), which stated that short mothers have higher likelihood of stunting in children by 1.81 times than normal-height mothers.

Based on the description above, it can be concluded that maternal height increase the likelihood of children's birth-length. Inherited maternal genetic were directly generated to their children. It was consistently significant that tall mothers would most likely to have tall children and otherwise, short mothers were most likely to have short children. However, the growth of children was also influenced by external factors such as adequate nutritional intake. The fulfillment of children's nutritional intake would pursue the delay of growth and children development (Desmond, 2017).

A study by Perkins et al. (2017), reported that the children development often decreased in concentration, isolation from the social environment, decreased cognitive function, poor learning, and low educational attainment in the future.

\section{The relationship between maternal age at pregnancy and child deve- lopment through stunting}

The result of this study showed that there was a significant relationship between maternal age at pregnancy and child development through stunting. This study was in line with a study by Singh et al., (2016) which stated that 18 years old or older mothers have 0,52 lower risk compared to 17 years old or younger mothers.

Based on the description above, it can be concluded that at the age of less than 20 years, young mothers still need adequate nutrients to grow up to mature age. Nutritional needs in pregnancy among young mothers become larger because the nutritional intake would be needed by the baby and the mothers. If the infant's nutritional intake was not fulfilled, then the infants would take a backup from the mothers and the risk of malnutrition was greater in children born to mothers who get married and get pregnant at young age (Darteh et al., 2014: Delprato et al., 2017). Linear growth in the first thousand days of life was essential for brain development, if it was not supported with sufficient nutritional intake, then the brain development would also be hampered. This can affect the children's cognitive development in the future (Desmond and Casale, 2017).

\section{The relationship between current maternal education and child deve- lopment through maternal age at pregnancy}

The result of this study showed that there was a significant relationship between current maternal education and child development through maternal age at pregnancy. The result of this study was in 
accordance with Géa-horta et al., (2016), who stated that the chances of a double burden of malnutrition were significantly higher among mothers with low levels of education.

Based on the description above, it can be concluded that education has an important role in changing individual's mindset. In the last few years, the time development has changed with the support of sophisticated technology. The prediction of the next years was to reduce the marriage at a young age due to rapid educational progress and the need of many people, forcing the adolescents to pursue higher education. Women who married at 20 years old or older were more likely to visit health services, antenatal and postnatal check up, thus minimizing the likelihood of short children, infectious diseases in children, and neonatal mortality. Marriage and pregnancy at young age would significantly increase the occurrence of stunting in children due to the lack of nutrition in pregnancy, this could be changed if a mother has high level of education, therefore, she can access and proccess the latest health information (Delprato and Darteh, 2017).

\section{The relationship between maternal} height and child development through birth-length and stunting

The result of this study showed that there was a significant relationship between maternal height and child development through birth-length and stunting. This study was supported by a study done by Géa-horta et al., (2016) which stated that mothers with normal height or taller decrease the risk of stunting in children by three times. This was also supported by maternal education, mothers with low levels of education have less ability in allocating financial resources and low knowledge of mothers about buying healthy food.

Based on the description above, it can be concluded that genetic factors directly become the basis and main factor in determining the development of individuals since the time of conception and inherited from parents through genes. Maternal factors became factor that affect the height of the children (MAL-ED, 2017). Therefore, short body-length was closely related to short posture of the mother. This mean that a mother with a short height became a risk factor of short-length baby and continued until the childhood, therefore, the child was shorter than the children in his/her age.

Short mother's posture was directly related to the period of conception, pregnancy and growth failure in children (Demirchyan et al., 2016). Therefore, the counseling about nutrition and stimulation of early childhood development in mothers was expected to increase the domain of child development so that children can pursue developmental delays (Perkins et al., 2017).

8. The relationship between maternal age at pregnancy and child development through birth-length The result of this study showed that there was a significant relationship between maternal age at pregnancy and child development through birth-length. This study was in line with a study Ramos, et al., (2015) which stated that 24 years old mothers showed stunting percentage by $11.7 \%$, this result was higher than mothers above 24 years old. This was not only due to maternal age, but from the socioeconomic factors, the mother with overweight, and maternal education was also contributed to the occurrence of stunting in children.

Based on the description above, it can be concluded that there were many factors that affect the short-length children. One of 
the factors that need to be considered was the maternal age at pregnancy. Maternal age at pregnancy of less than 20 years did not have the adequate experience and knowledge to care about her pregnancy (Chirande et al., 2015). While 35 years old or older pregnant mothers tend not eager to care for their pregnancies. In older mothers, there was also a decrease in the absorption of nutrients that would lead to unbalanced food intake and lead to malabsorption, therefore, the nutritional needs in infants were unfulfilled. The quality of psychiatric conditions and the readiness of the mothers during pregnancy affect the baby. The quality of the babies was measured anthropometrically by birthweight and birth-length of the baby (Sukmani, 2016).

Ramos et al. (2015) stated that mothers with higher levels of education provide better care to children because of the enhancement of knowledge, and the information and access to health care were influenced by the level of education, therefore, it could prevent delayed child development.

\section{The relationship between family income at pregnancy and child development through birth-length and stunting}

The result of this study showed that there was a significant relationship between family income at pregnancy and this study was supported by a study by Haile et al. (2016) which stated that children with poor families have 1,41 times higher likelihood to the occurrence of stunting than children who have rich family.

Based on the description above, it can be concluded that family income at pregnancy enhanced child development, birthlength, and stunting which was in accordance with previous studies and existing theories. Family's socio-economic has always been associated with aspects of health and development of children who have an effect on the future life (Conant et al., 2017). Wealthy families would be able to get better children's health services including nutrition fulfillment (Darteh et al., 2014).

The result of this study showed that there was a significant relationship between family income at pregnancy and this study was supported by a study by Darteh et al., (2014) which stated that there was a significant relationship between household's wealth and stunting. Children with high family income were o,34 time less likely to have stunting than children with low family income. This was in line with a study done by Haile et al., (2016) which stated that children with poor families were 1,43 times more likely to have stunting than children who have rich family.

\section{REFERENCES}

Addo OY, Aryeh DS, Caroline HF, Denise PG, Aravinda MG, Bernardo LH, et al. (2013). Maternal Height and Child Growth Patterns. The Journals of Pediatric: J Pediatr. 163: 549-54.

Aguayo VM, Nina B, Kajali P (2015). Determinants of Child Stunting in the Royal Kingdom of Bhutan: an inDepth Analysis of Nationally Representative Data. Maternal \& Child Nutrition published by John Wiley \& Sons Ltd Maternal and Child Nutrition: $333-345$.

Armstrong MEG, MI Lambert, EV Lambert (2011). Secular Trends in the Prevalence of Stunting, Overweight and Obesity among South African Children (1994-2004). European Journal ofClinical Nutrition, 65: 835-840.

Aryastami NK, Anuraj S, Nunik K, Besral, Abas BJ, Endang A (2017). Low Birth Weight was the most Dominant Pre- 
dictor Associated with Stunting among Children aged 12-23 months in Indonesia. BMC Nutrition, 3:16.

Atsu BK, Chris G, Amos KL (2017). Determinants of Overweight With Concurrent Stunting Among Ghanaian Children. BMC Pedriatic, 17: 177.

Barker JPD, Clive O, Tom JF, Kent LT, Eero K, Johan GE (2013). Foetal and Childhood Growth And Asthma In Adult Life. Published by John Wiley \& Sons Ltd, 102: 732-738.

Bove I, Teresa M, Cristina C, Ricardo U, MN (2012). Stunting, Overweight and Child Development Impairment go Hand in hand as Key Problems of Early Infancy: Uruguayan Case. Early Human Development 88: 747-751.

Casale DC, Desmond, Richter L (2014). The Association Between Stunting And Psychosocial Development Among Preschool Children: A Study Using The South African Birth To Twenty Cohort Data. Child: Care, Health and Development. Published by John Wiley \& Sons Ltd, Child: care, health and development, 40(6): 900-910

Conant LL, Einat L, Anjali D, Jeffrey R. Binder (2017). The Relationship Between Maternal Education And The Neural Substrates Of Phoneme Perception In Children: Interactions Between Socioeconomic Status And Proficiency Level. Brain \& Language. ElsevierInc. 171: 14-22.

Darteh EKM, Evelyn A, Akwasi KK (2014). Correlates of Stunting Among Children in Ghana. BMC Public Heath: 14: 504.

Decker ED, Craemer MD, Bourdeaudhuji ID, Wijndaele K, Duvinage K, Koletzko B, Grammatikaki E, Lotova V, Usheva $\mathrm{N}$, et al (2012). Influecing Factors of Screen Time in Preschool Children: An Exploratin of Parents
Perception Through Focus Groups in Six European Countries. Obesity Reviews, 13(1): 75-84.

Darteh EKM, Evelyn A, Akwasi KK (2014). Correlates of Stunting Among Children in Ghana. BMC Public Heath. 14: 504.

Delprato M, Kwame A (2017). The Effect of Early Marriage Timing onWomen's and Children's Health in Sub-Saharan Africa and Southwest Asia. Elsevier. 3: 3-4.

Desmond C, Casale D (2017). Catch-up Growth in Stunted Children: Definitions and Predictors. PLoS ONE 12(12): e0189135

Dorélien AM (2016). Effects of Birth Month on Child Health and Survival in SubSaharan Africa. Public Access, 61(2): 209-230.

Murti B (2007). Sejarah Epidemiologi.

Fernalda LCH, Patricia K, Melissa H, and Paul JG (2012). Socioeconomic Gradients In Child Development In Very Young Children: Evidence from India, Indonesia, Peru, and Senegal. PNAS, 109(2): 17273-17280.

Fikadu T, Sahilu A, Lamessa D (2014). Factors Associated With Stunting Among Children Of Age 24 To 59 Months In Meskan District, Gurage Zone, South Ethiopia: A Case-Control Study. BMC Public Health, 14: 800.

GéaHT, Rita DC, Ribeiro S, Rosemeire LF, Maurício LB, Gustavo VM (2016). Factors Associated With Nutritional Outcomes In The Mother-Child Dyad: A Population-Based CrossSectional Study. Public Health Nutrition: 19(15): 2725-2733.

Haile D, Muluken A, Tegegn M, Rochelle R (2016). Exploring spatial Variations And Factors Associated With Childhood Stunting In Ethiopia: Spatial And Multilevel Analysis. BMC Pedia- 
trics: $1-14$.

Hizni A, Madarina J, Gamayanti IL (2010). Status stunted dan Hubungannya dengan Perkembangan Anak Balita di Wilayah Pesisir Pantai Utara Kecamatan Lemahwungkuk Kota Cirebon. Jurnal Gizi Klinik Indonesia. 6(3): 131-137.

Islam MM, Kazi IS, Mustafa M, Shamsir A, Dinesh M, Rashidul H, Tahmeed A (2018). Risk Factors of Stunting Among Children Living in an Urban Slum of Bangladesh: Findings of A Prospective Cohort Study. BMC Public Health. 18: 197.

Kementrian Kesehatan RI (2015). Pendek (Stunting) di Indonesia, Masalah dan Solusinya. Jakarta: Badan Penelitian dan Pengembangan Kesehatan (2015) pendek (stunting) di Indonesia.

Kementrian Kesehatan RI (2016). Pemantauan Status Gizi Dan Indikator Kinerja Gizi. Jakarta.

(2016). Situasi Balita Pendek.Pusat

Data dan Informasi Kementrian Kesehatan RI. Jakarta.

(2017). Pemantauan Status Gizi (PSG) Dan Penjelasannya. Jakarta.

Kim R, MejíaG, Ivá C, Aguayo VM, Subramanian SV (2017). Relative Importance Of 13 Correlates Of Child Stunting In South Asia: Insights From Nationally Representative Data From Afghanistan, Bangladesh, India, Nepal, and Pakistan. Social Science \& Medicine.

Morrison AP, Paul F, Suzanne LKS, Max B, David, Fawler, Andrew IG, Peter BJ, et al. (2012). Early detection and intervention evaluation for people at risk of psychosis: multisite randomised controlled trial. BMJ. 344. doi: https://doi.org/10.1136/bmj.e2233.

Nurbaeti TS (2016). Stunting Degree Relationship with Fine Motor Develop- ment of Children Aged 12-24 Months. Jurnal Kesehatan Masyarakat. 1(4).

Onis MD, Francesco B (2016). Childhood Stunting: a Global Perspective.World Health Organization; licensed by JohnWiley \& Sons Ltd. Maternal \& Child Nutrition, 12 (1): 12-26.

Perkins JM, Kim R, Krishna A, McGovern M, Aguayo VM, Subramanian SV (2017). Understanding the Association Between Stunting And Child Development in Low- and MiddleIncome Countries: Next Steps For Research and Intervention. Social Science \& Medicine.

Rahman MS, Howlader T, Masud MS, Rahman ML (2016). Association of Low-Birth Weight with Malnutrition in Children Under Five Years in Bangladesh: Do Mother's Education, Socio-EconomicStatus, and Birth Interval Matter?. PLoS ONE 11(6): e0157814.

Ramos CV, Dumith SC, César JA (2015). Prevalence and Factors Associated with Stunting and Excess Weight in Children Aged 0-5 Years from the Brazilian Semi-Arid Region. J Pediatr (Rio J). 91: 17582.

Schady N (2011). Parents Education, Mothers Vocabulary and Cognitive Development in Early Childhood: Longitudinal Evidence from Ecuador. American Journal of Public Health: 101(12): 2299-2307.

Singh A, Upadhyay AK, Kumar K (2016). Birth Size, Stunting and Recovery from Stunting in Andhra Pradesh, India: Evidence from the Young Lives Study.Maternal and Child Health Journal. Springer US. doi: 10.1007/s10995-016-2132-8.

UNICEF (2012). Gizi Ibu dan Anak. UNICEF Indonesia.

Win KM, Marc VDP, Nitaya V, Kwanjai A 
Journal of Maternal and Child Health (2018), 3(1): 68-80

https://doi.org/10.26911/thejmch.2018.03.01.07

(2013). Early Pregnancy and Maternal Malnutrition as Precursors of Stunting in Children under Two Years of Age among Bhutanese Refugees, in
Nepal Maternal. Thammasat International Journal of Science and Technology, 18(1). 